Utah State University

DigitalCommons@USU

1977

\title{
Field studies of pine, spruce and aspen periodically subjected to sulfur gas emissions
}

\author{
A.H. Legge \\ D.R. Jaques \\ R.G. Amundson \\ R.B. Walker
}

Follow this and additional works at: https://digitalcommons.usu.edu/aspen_bib

Part of the Forest Sciences Commons

\section{Recommended Citation}

Legge, A. H.; Amundson, R. G.; Jaques, D. R.; Walker, R. B. 1976. Field studies of pine, spruce and aspen periodically subjected to sulfur gas emissions. In: Dochinger, L. S.; Seliga, T. A., eds. Proceedings of the first international symposium on acid precipitation and the forest ecosystem; Gen. Tech. Rep. NE-23. Upper Darby, PA: U.S. Department of Agriculture, Forest Service, Northeastern Forest Experiment Station. 1033-1061

This Article is brought to you for free and open access by the Aspen Research at DigitalCommons@USU. It has been accepted for inclusion in Aspen Bibliography by an authorized administrator of DigitalCommons@USU. For more information, please contact

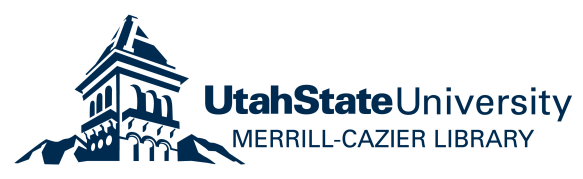


FIELD STUDIES OF PINE, SPRUCE AND ASPEN

PERIODICALLY SUBJECTED TO SULFUR GAS EMISSIONS

A. H. LEGGE, Environmental Sciences Centre (Kananaskis), The University of Calgary, Alberta; R. G. AMUNDSON, Department of Botany, University of WAshington, Seattle; D. R. JAQUES, Environmental Sciences Centre (Kananaskis), The University of Calgary, Alberta; and R. B. WALKER, Department of Botany, University of Washington, Seattle.

\section{ABSTRACT}

Field studies of photosynthesis in Pinus contorta/Pinus banksiana (lodgpole pine/jack pine) hybrids, Picea glauca (white spruce) and Populus tremuloides (aspen) subjected to $\mathrm{SO}_{2}$ and $\mathrm{H}_{2} \mathrm{~S}$ from a nearby natural gas processing plant were initiated near Whitecourt, Alberta, Canada during the summer of 1974. The site was characterized as a PinusPicea glauca/Arctostaphylos uva-ursi association (pine-white sprućc/bearberry). A 15 meter high scaffold was used as access to mid-crown foliage in the pines while the spruce and aspen were accessible from the ground. Net assimilation rates, transpiration rates and leaf resistances were calculated and water deficits were monitored. Photosynthetic rates measured were in a low range for the conifers studied, with pine having a maximum of $3.28 \mathrm{mg} \mathrm{dm}^{-2} \mathrm{hr}^{-1}$ and white spruce a maximum value of $2.3 \mathrm{mg} \mathrm{dm}^{-2} \mathrm{hr}^{-1}$. The low maximum photosynthetic rate determined for aspen is thought to be attributable to the onset of autumn. Chemical analyses for $\mathrm{SO}_{4}$-sulfur using the methylene blue colorimetric method of Johnson and Nishita (1952) showed levels of 300-700 ppm, with the older foliage showing slightly higher values. Visible chronic $\mathrm{SO}_{2}$ symptoms had a pronounced sun, or upward, orientation. Ambient $\mathrm{SO}_{2}, \mathrm{H}_{2} \mathrm{~S}$ and total $\mathrm{S}$ were measured using á Tracor 270HA Atmospheric Sulfur Analyzer (chromatographic method) and trends in ambient $\mathrm{SO}_{2}$ concentrations using an Envirometrics $\mathrm{SO}_{2}$ Analyzer (polarographic method). Concentration was found to be variable for $\mathrm{SO}_{2}$ and generally below $0.05 \mathrm{ppm}$. A concentration gradient of $\mathrm{SO}_{2}$ was found to exist in the lodgepole pine/jack pine stand with the $\mathrm{SO}_{2}$ values above the canopy generally higher than below the canopy ( $0.1 \mathrm{ppm}$ above and $0.05 \mathrm{ppm}$ below). This condition was occasionally reversed. The plant canopy is considered to act as a barrier to downward diffusion of the sulfur emissions in the first case and also a barrier to upward diffusion of sulfur 
emissions present due to advection in the stand in the second case. The vegetative environment surrounding the windfall Gas Plant is definitely affected by sulfur gas emissions but the extent remains to be determined.

\section{INTRODUCTION}

Specific damage and even elimination of plant species from areas exposed to sulfur gas emissions such as $\mathrm{SO}_{2}$ have often been documented (Scheffer and Hedgecock, 1955; Bowen, 1965; Westman, 1974; Skorepa and Vitt, 1975). Air quality sampling trailers are used extensively today to monitor air pollutants. It is difficult if not impossible, however, to estimate "damage" or impact from air pollutants upon vegetation without a knowledge of the many environmental variables, in addition to pollutant dose, that can modify plant response. An extensive research effort is needed to determine the short term and long term effects of high and low concentrations of sulfur gas emissions on vegetation in the field.

The main objective of this study was to begin answering specific questions about the effects of sulfur gas emissions on several dominant plant species periodically exposed to a point source in the field:

(1) What is the nature of the plant communities surrounding the point source emission?

(2) What is the ecophysiological status of several dominant plant species Pinus contorta/Pinus banksiana (lodgepole pine/jack pine), Picea glauca (white spruce) and Populus tremuloides (aspen) under "as it is" field conditions?

(3) What is the nature and composition of the ambient atmosphere in terms of $\mathrm{SO}_{2}$ and $\mathrm{H}_{2} \mathrm{~S}$ using the methods of gas chromatography and polarography?

The experimental site is located approximately one-half mile east of the AMOCO Windfall Gas Plant in the Whitecourt area of the sour gas corridor of western Alberta and is shown in plate 1 and plate 2. This area was chosen for study for several important reasons:

(1) presence on the vegetation of classic symptoms indicating stress from sulfur gas emissions;

(2) extensive background data already available for the area; 


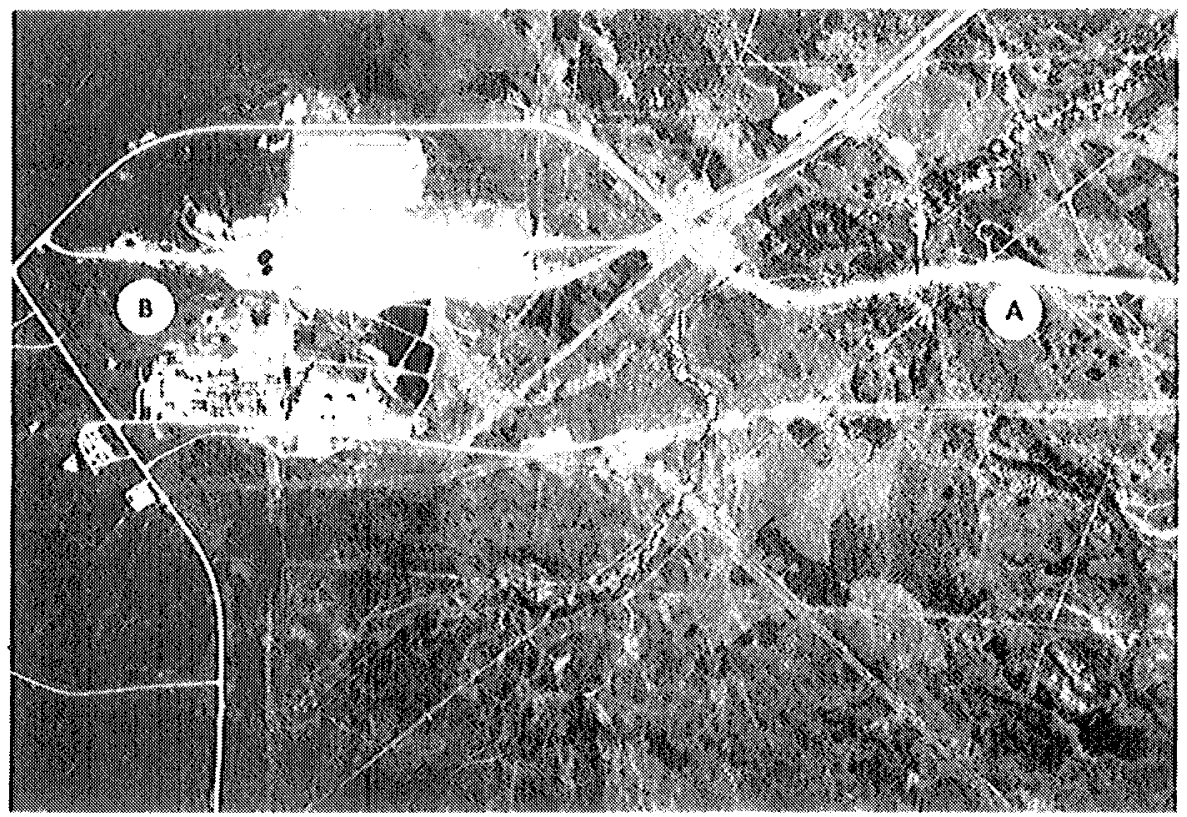

plate 1. False color infrared aerial photograph showing spatial relationship between experimental. ecophysiological test site on sand dune $(A)$ and the AMoco windfall. Gas plant $(B)$. The study area is east of the gas plant. The effects of the 1956 fire axe readily identifiable by the patchwork nature of: the vegetation.

scale: $1: 30,000$

Tmagexy supplied by TNIERA Envixomental Consultants utd.

(3) similarity in plant species compostition between this site and similar areas in the region of the Athabasca Tar sands, thus making the data generated txansfexrable;

(4) availability of line powex; and

(5) excellent cooperation with the gas processing industry via the Whitecourt Invironmental. Study Group member companies.

Since the study axea is located near the windfall Gas plant, it must be remembered that the primary point sources were the flare stacks rathex than the incinexator stacks. 


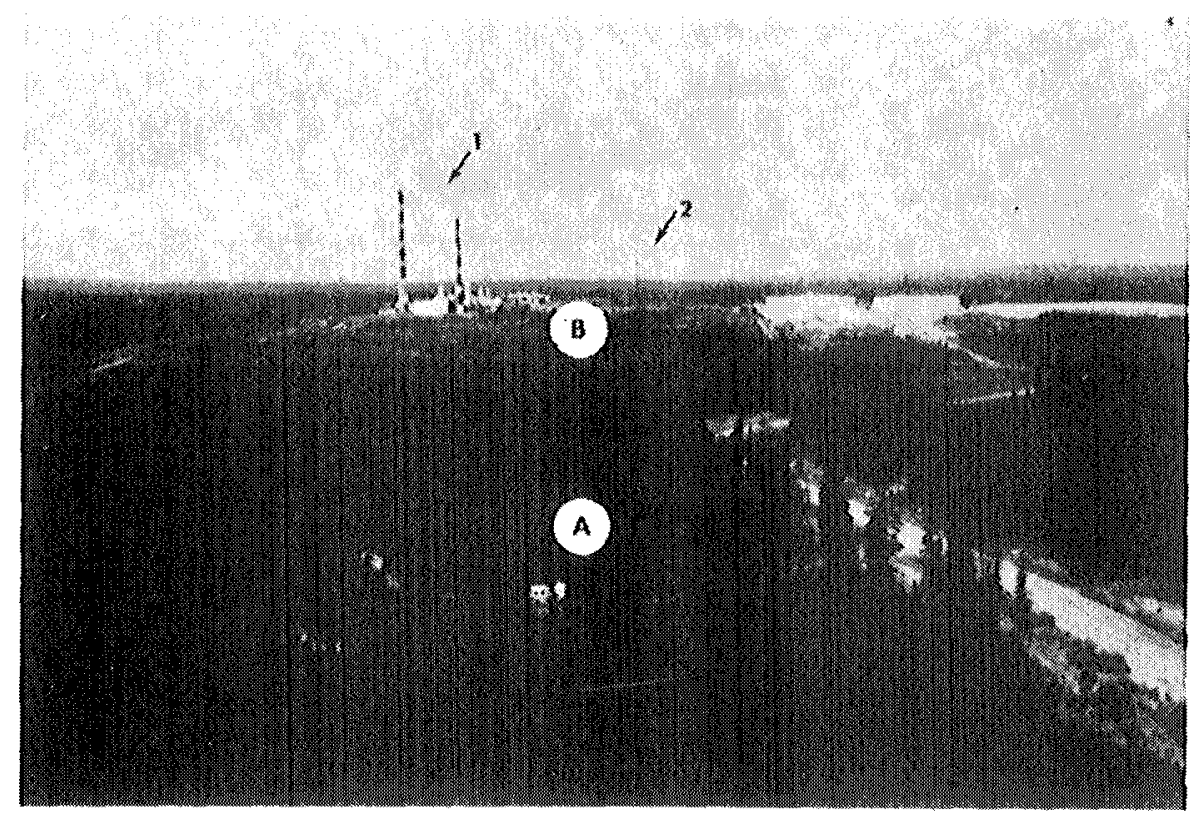

plate 2. Aerial color oblique showing relationship between experimental ecophysiological test site (A), instrument trailex, 15 meter access towex to midcrown foliage of lodgepole pine/jack pine hybrids in the foreground and the AMOCO Windfall Gas plant (B) in the background and to the west. The red and white striped incinexator stacks are indicated by (1) and the flare stacks by (2). Note the undulating nature of the topography.

\section{STTF CLASSTETCATTON AND DESCRTPTION}

The vegetation of the Whitecourt, nlberta area is included in the "predominantly forest" subregion of the Boreal Forest Region of Canada by Halliday (1937). Rowe (1972) has further subdivided the Boreal. Eorest Region into 45 distinct geographic areas with the Whitecouxt area located in the lower foothills area (B.19a). This area is characterized as a transition forest area between the Boreal and the Subalpine Forest Regions. The transitional nature of the vegetation is emphasized by the fact that two common species of trees occurring in the axea are actually represented by populations of hybrid individuals between pinus contorta and pinus banksiana while the true fir in the area represents hybrids between Abies lasiocarpa and Abies balsamea. 
Variability in natural plant communities in the whitecourt area in the vicinity of the Windfall. Gas plant is naturally complex, but this complexity has been intensified due to past disturbance of the area by fire in 1.956 and by seismic exploration. The subdued undulating topography also contributes to gradual envixonmental gradients causing subtle variation in community composition and structure from location to location (plate 2). Two distinct sites offer fairly uniform and repeatable habitats for vegetative community development. These are wel1-arained vegetated sand dune sites and moist bogs. These two sites exhibit plant comnunities that are remarkably uniform and repeat themselves consistently across the landscape. Only the sand dune site, one half mile east of the AMOCO Windfall. Gas plant, will be described in detail since it was the location of the ecophysiological analysis during the late summer of 1974 (plate 3).

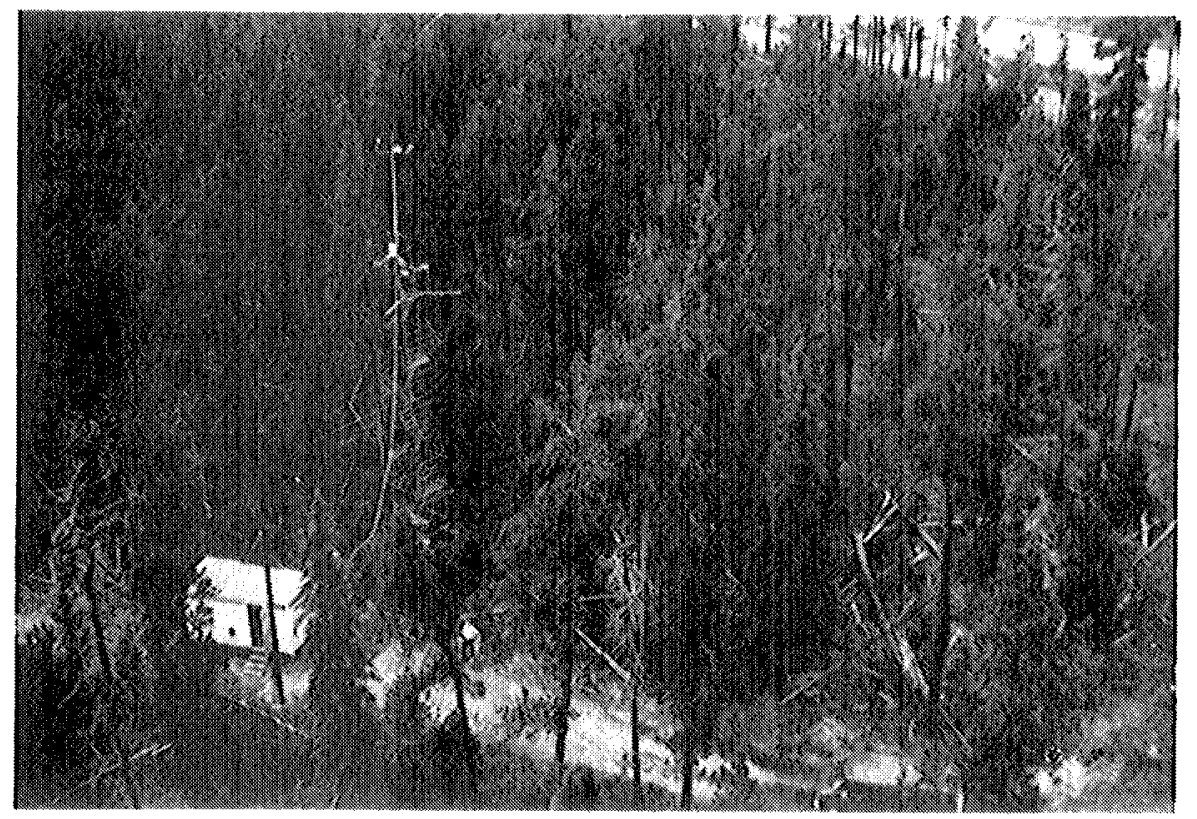

plate 3. Expeximental test site one-half mile east of the AMOCO Windfal1 Gas plant showing the mature stand of pinus contorta/pinus banksiana hybxids with 15 meter access tower scaffolding and instrument trailer. Note the open nature of: the stand and the dominance of the pine.

The plant association occurring on this sand dune site has been characterized following standard phytosociological techniques (Daubenmixe, 1968). Table 1 shows the overstory and understory in this single-layered, even-aged stand. pine and spruce reproduction are both moderately light, and since the pine is clearly dominating 
Table 1: Phytosoctological analysis of a pine stand on a sand dune near the Windfall cas plant, Whitecourt, Alberta.

Overstory Components

\begin{tabular}{|c|c|c|}
\hline Spectes & Stens/heetare & Diameter (chos) \\
\hline Picea glauca (whlte spruce) & 400 & 18.4 \\
\hline pinus contorta $p$. banksiana (lodgepole $\times$ jack pine) & 533 & 22.7 \\
\hline Picea reproduction & 1680 & $\cdots$ \\
\hline Pinus reproduction & 3680 & $-\cdots$ \\
\hline Toral & 6293 & \\
\hline
\end{tabular}

Understory components

\begin{tabular}{|c|c|c|}
\hline Spectes & Percent cover & Percent presence \\
\hline Vaccinium vitis-idaea (bog cranberry) & 40.0 & 100 \\
\hline Vacciniun myrtilloides (blueberry) & 8.7 & 92 \\
\hline Arctostaphylos uva-ursi (bearberry) & 8.1 & 46 \\
\hline Elymus imovatus (hatry wild rye) & 3.8 & 77 \\
\hline Lycopodium complanatum (ground cedax) & 5.8 & 31 \\
\hline Cornus canadensis (bunchberry) & + & 15 \\
\hline Ledum gromlandicum (Labrador tea) & 1.5 & 87 \\
\hline Campanula rotundifolia (bluebell) & + & 23 \\
\hline Anelanchier alnifolia (Saskatoon berry) & + & 15 \\
\hline Haianthemun canadense (111y-of-the-yalley) & 4 & $4+$ \\
\hline Solidago canadensis (goldenxod) & + & 14 \\
\hline Lonicera involucrata (bracted hyneysuckle) & + & +1 \\
\hline Potentilla tridentata (three-toothed cinquefoll) & + & +1 \\
\hline Geocaulon lividum (fern) & + & $+1+$ \\
\hline Galium boreale (northern bedstraw) & + & $+\$$ \\
\hline Dicramum polysotum & + & +4 \\
\hline Pleurorium schreberi & + & +1 \\
\hline TOTAL & $6 \% .9$ & $\ldots$ \\
\hline
\end{tabular}

+ less than $1 \%$ cover

th pregent in only whe microplot

hexe, it seems that an edaphic climax community of pine is developing on this wel1-arained dune. The five indicatox species of this pine-spxuce/bearberry association (pinus-picea glauca/Arctostaphylos uvamursi assoclation) are pine (Pinus contorta $\times$ P. banksiana), white spruce (pjcea glauca), bearberry (Arctostaphylos uva-ursi), haixy wild rye (Elymus innovatus), and blueberry (Vaccinium myrtilloides).

With bog cranberry (Vaccinium vitismidaea) dominating the understory at this particulax site one is led to believe that this site has higher moisture holding capacity, at least in the A horizon, than is common for this association in othex areas where blueberry (Vaccinium myxtilloides) is clearly dominant over $v$. vitismidaea. The soil on this site is a rapidy dxained sand. Sevexal samples show the subsoil to be more than 90 per cent sand, $5-8$ per cent silt and 1 per cent ox less clay. The surface soil, however, has a loamy sand texture. The soil can be classed as a degraded eutric Brunisol, indicating a comparatively high base saturation for this soil.

In terms of forest productivity measured as basal area, this site is very low on the scale with a value of approximately $35 \mathrm{~m}^{2} / \mathrm{ha}$. other workers have computed basal axea values for conifers at other 
sites in North America and these range from highs of $145 \mathrm{~m}^{2} / \mathrm{ha}$ to lows of $56 \mathrm{~m}^{2} / \mathrm{ha}$ (Daubenmire, 1968; Whittaker, 1956). Daubenmire (1968) has also shown basal area to be closely correlated with ecological site classification. When sites are carefully chosen based upon homogeneity of vegetation composition and structure, this close relationship is apparent. Not only does total productivity vary according to ecological units of vegetation classification but also individual species vary in productivity from site to site. This concept is illustrated utilizing lodgepole pine/jack pine from the Windfall area.

Figure 1 shows the annual increment in basal area production for

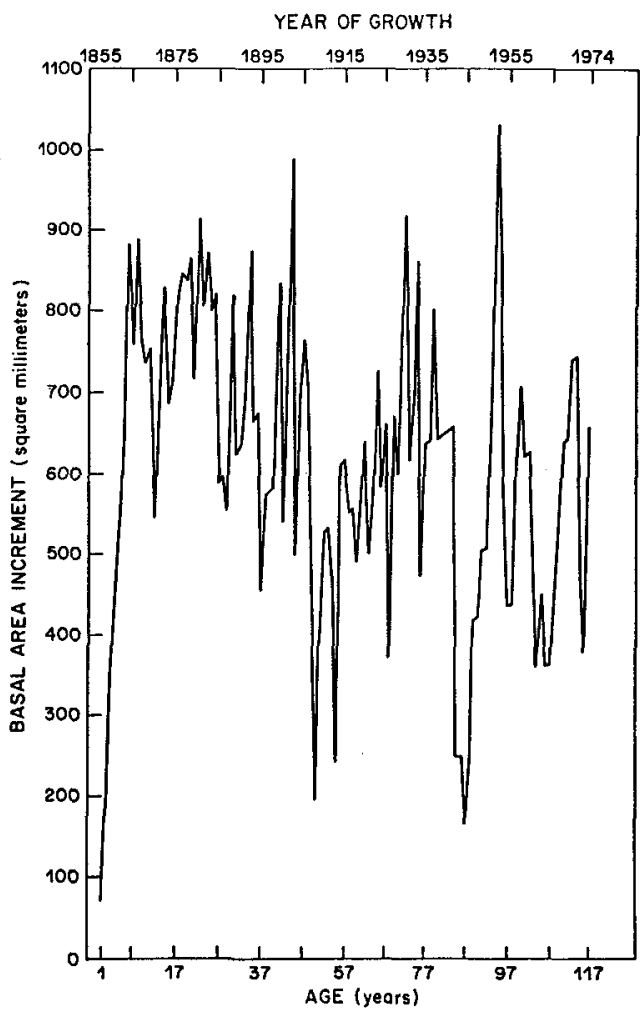

Figure 1. Hybrid lodgepole pine/jack pine annual basal area increment of growth in the PinusPicea/Arctostaphylos uva-ursi (pine-spruce/bearberry) plant association on the experimental sand dune site. Note the fluctuation around a long term basal area increment average.

pine at the experimental dune site where it is a dominant part of the overstory. Figure 2 shows the same annual increment in basal area for pine in a Picea mariana/Ledum-Sphagnum (black spruce/Labrador teasphagnum) bog site adjacent to the sand dune site where the pine is only occasional in its occurrence. The growth increments are significantly different at the 0.1 per cent level of probability (average annual increment $=620 \mathrm{~mm}^{2} /$ year for the tree in figure 1 and $272 \mathrm{~mm}^{2} /$ year for the tree in figure 2). Although the sample size is too small to say that this relationship holds throughout both plant associations, it is thought that both trees studied represent the 


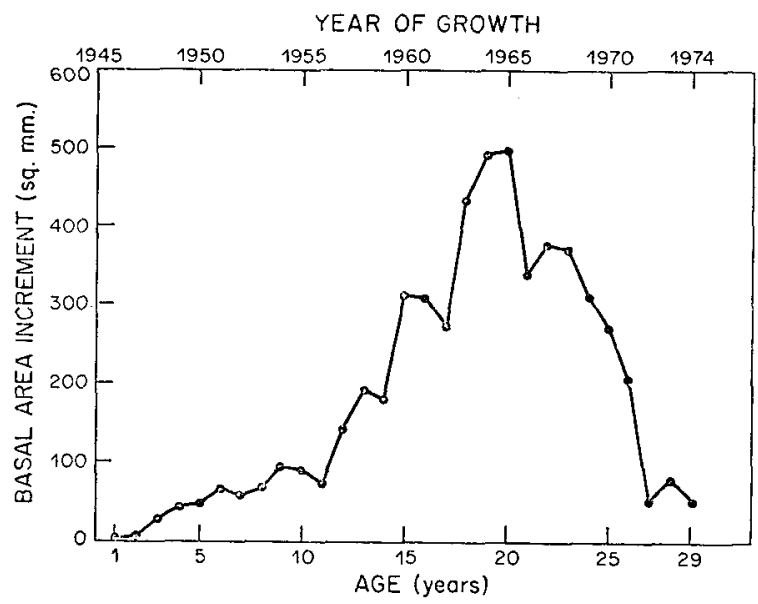

Figure 2. Hybrid lodgepole pine/jack pine annual basal area increment of growth in Picea marianal Ledum-Sphagnum (black spruce/Labrador tea-sphagnum) bog plant association, adjacent to Pinus-Picea/ Arctostaphylos uva-ursi (pine-spruce/bearberry) sand dune plant association. Pine only rarely occurs in this black spruce plant association. In contrast to the pine illustrated in figure 1 , productivity as measured by basal area increment is less than half that of the pine growing in the sand dune site. The pronounced decrease in basal area increment after 1965 is probably due to unfavorable moisture conditions (excess water) rather than the presence of sulfur gas emissions.

common pattern of growth for pine in each plant association.

Within the black spruce bog are small mounds which support some pine and blueberry (Vaccinium myrtilloides). These microtopographic rises are better drained than the black spruce bog itself. As a consequence pine growth more closely approximates that on the dune site (as shown when figure 3 is compared to figure 1). Average annual increment for the pine in figure 3 is $700 \mathrm{~mm}^{2} /$ year while that for the tree in figure $I$ is $620 \mathrm{~mm}^{2} /$ year (no significant difference in growth detected).

Another factor of large importance when comparisons of growth before and after some outside influence or stress is placed on a plant is the natural change in growth patterns throughout the life span of any given plant. Net photosynthetic rates as well as the amount of photosynthate utilized in construction of woody tissues in conifers will vary with the age of the plant, time of year and environmental factors. This fact is illustrated in figure 1 by comparing the first few years of growth. A rapid increase in basal area increment for 


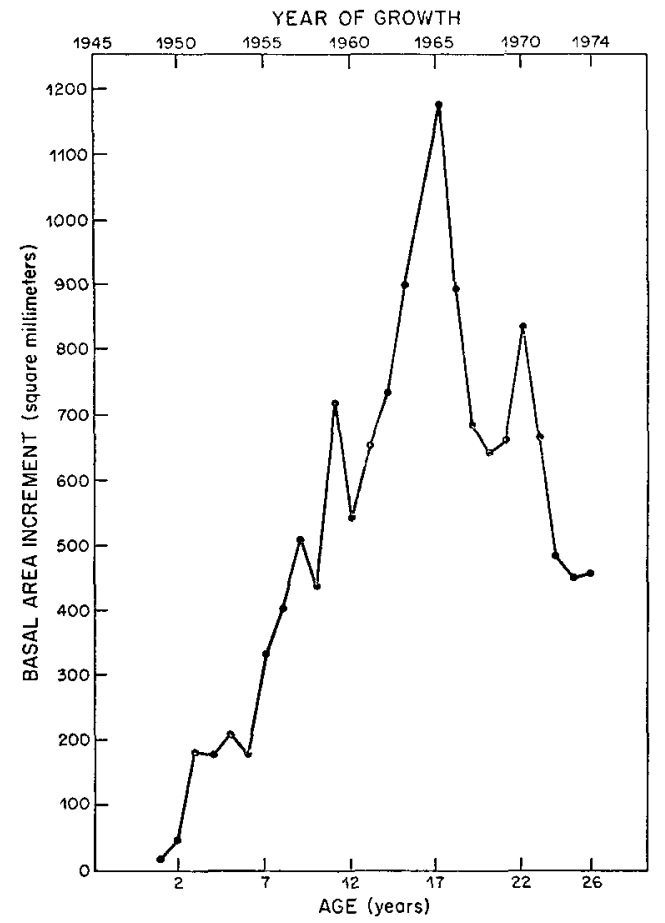

Figure 3. Hybrid lodgepole pine/ jack pine annual basal area increment of growth on a mounded inclusion of Pinus-Picea/ Arctostaphylos uva-ursi (pinespruce/bearberry) association vegetation in a Picea mariana/ Ledum-Sphagnum (black spruce/ Labrador tea-sphagnum) association. The more than 100 per cent increase in basal area increment of this pine in contrast to the pine illustrated in figure 2 drastically illustrates the effect of microsite on plant productivity. The pronounced decrease in basal area increment after 1965 is probably due to unfavorable moisture conditions (excess water) rather than the presence of sulfur gas emissions.

this 117 year old tree is seen in the first 10 to 15 years of growth, followed by growth rates which begin to level off and fluctuate around a long-term average. Senility does not appear to have begun in the oldest trees on the dune site (see figure 1) despite the presence of white pocket rot (Fomes pini). Lodgepole pine is known to reach ages of several hundred years in other areas although none of that age are common in the Boreal Forest Region.

Older trees such as the one illustrated in figure 1 are the only trees that provide a long enough record of yearly growth rates to make comparisons prior to and after any given date once the first 15-20 years of early growth are eliminated. Young pines (40-50 years old) do not provide acceptable working material for making these comparisons. The tree illustrated in figure 1 does, however, assuming that the last few years growth has not been affected by any consequences of senility. No significant difference in growth prior to 1961 and after 1961, when the Windfall Gas Plant began operations, is detected from the data graphed in figure 1 . However, only minor biological significance can be placed on this study for two major reasons: (1) the sampling site is much too small and (2) no control areas (similar ecological sites unaffected by the Windfall Plant) were compared to the affected site.

These few examples describe the complexity of the "growth" response (measured as basal area increment per year) in the same species over several different environmental conditions (i.e. different 
ecological conditions). Not only does the environment in which a seedling is established affect the growth rate of that seedling but also the genotypic makeup exerts controls on photosynthesis rates and thus basal area increment. The genetic controls of growth rates and patterns of growth will vary for the same species from site to site. Any organism, whether it be plant or animal, is a product of its genotype-environment interaction and the organism is continually exposed to simultaneous changes in many environmental parameters.

This initial study, aimed at describing the plant community on which the physiological experiments were conducted during the summer of 1974, has pointed to two recommendations for further study. These should be undertaken to provide the data to aid in assessing whether or not plant life in the vicinity of the windfall plant has been affected by the sulfur gas emissions.

The first is to conduct paired plot studies of basal area growth rates in black spruce, white spruce, birch, and/or aspen. Pine cannot be used, as ecologically similar sites are probably not available both in affected and unaffected locations. Plots would be paired based on ecological similarity of sites as determined by detailed phytosociological analysis of selected sites. Growth rates would be analyzed and compared prior to 1961 and after 1961.

The other method would also be based upon paired plot studies. The object of the study would be mosses, liverworts and lichens epiphytic on given tree species. Many studies have shown the sensitivity of these plants to atmospheric contaminants. The plot to be studied would be whole trees of a given height, age, diameter and growing in a given plant community. Similarity indices based on the cryptogamic flora and productivity of that flora would be compared in affected and unaffected sites. This sampling design would follow that of Pike et al. (unpubl. manuscript).

\author{
SULFUR DIOXIDE AND VEGETATION
}

SULFUR DIOXIDE AS AN ENVIRONMENTAL VARIABLE

Several reviews have considered the effects of $\mathrm{SO}_{2}$ on plants (Thomas, 1961; Daines, 1968; Tamm and Aronsson, 1972). They indicate that most studies have attempted to correlate dosage with measurable visible damage. Assuming comparable exposure conditions, it is generally accepted that for each plant there is a threshold value for the development of injury by $\mathrm{SO}_{2}$ (Thomas, 1961; Guderian and Van Haut, 197.0). 
Two distinct types of visible $\mathrm{SO}_{2}$ plant damage have been recognized by most workers: acute damage that occurs with high dosages (over $1.0 \mathrm{ppm}$ ) of short duration and chronic damage that appears after long periods at low or intermittently low dosage (less than 0.2 ppm or between 0.2 and $1.0 \mathrm{ppm}$ ). More recently, however, in a report to the Whitecourt Environmental Study Group (1973, Section 1: Surface Environment; B. Foliar symptoms as a monitor of environmental stress, 1-8 through 1-17) visible $\mathrm{SO}_{2}$ symptomology was divided into three types: transient, chronic and acute. This division is much more realistic as it describes symptoms in terms of longevity as well as degree. It works well in describing the status of the vegetation under field conditions exposed to sulfur gas emissions. It is impossible at present, however, to assign a meaningful concentration of a pollutant or pollutants under field conditions which will elicit these symptoms. This may be possible in the future when air quality trailers are monitoring environmental parameters other than pollutants, wind speed and direction, and temperature (next to or above the trailer) such as relative humidity (or absolute water content of air), photosynthetically active radiation (PAR) and soil moisture. It is further critical to determine what plant communities are exposed to in terms of pollutants and their concentration. Research on the meaningfulness of monitoring techniques is urgently needed.

Certain environmental parameters, such as high relative humidity and soil moisture, with moderate light intensity and temperature (above $5^{\circ} \mathrm{C}$ ), will make vegetation more susceptible to damage from air pollutants. The extent of $\mathrm{SO}_{2}$ injury is primarily determined by the status of the stomatal pores (Scheffer and Hedgecock, 1955; Stratmann, 1960; Meidner and Mansfield, 1968; Lopushinsky and Klock, 1974). The degree to which these pores are open or closed (stomatal aperture) controls the rate of gas transfer $\left(\mathrm{CO}_{2}\right.$ and $\left.\mathrm{SO}_{2}\right)$ to and from the external ambient environment and the internal plant environment. The $\mathrm{SO}_{2}$ which enters the plant through the stomatal pores readily enters solution in the thin layer of water surrounding the mesophyll cells (outer layer of internal cells) and is slowly oxidized from sulfite and bisulfite, the more damaging forms, to sulfate (Thomas and Hill, 1937). Tanaka et al. (1974), using alfalfa leaf homogenate, showed a 50 per cent decrease in ${ }^{14} \mathrm{CO}_{2}$ fixation caused by a $3 \times 10^{-2} \mathrm{M}$ concentration of sulfite ion, but no effect from the same concentration of sulfate ion. They attributed this reduction to an inhibition of the enzyme ribulose-1, 5-diphosphate carboxylase by sulfonation of its - SH groups.

Although sulfite is more inhibitory than sulfate in short-term exposures, evidence indicates (Thomas et al., 1950) that over long exposures to excess sulfur, sulfate buildup in the tissues is damaging. Thus, although chlorosis and early leaf loss are recognized as symptoms of chronic $\mathrm{SO}_{2}$ damage, detection of high levels of sulfate-sulfur by plant-tissue analysis is a more reliable indicator of potentially damaging sulfur (Ulrich et al., 1967). 
For photosynthesis under controlled-environment conditions, optimal levels of light, temperature, soil moisture and relative humidity have been determined for many species using $\mathrm{CO}_{2}$ gas-exchange methodology. Among these studies was the work done on species associated with the mixed forests of west central Alberta by Dykstra (1974) who studied Pinus contorta (lodgepole pine) and Van Zinderen Bakker (1974) who worked with Picea mariana (black spruce). This work provides essential background information for the Whitecourt area.

The gas-exchange technique has only recently been applied to the study of the effects of air pollutants on plant life under controlled conditions in the laboratory. Hickling (1974) working on Pseudotsunga menziesii (Douglas fir) reported both inhibitory and stimulatory effects of low levels of $\mathrm{SO}_{2}$ on net assimilation and transpiration with short-term exposures. $\mathrm{SO}_{2}$ was shown to have a direct effect on the degree of opening of stomata by Majernik and Mansfield (1970; 1971) in Vicia faba (broad bean). These workers showed that levels of $\mathrm{SO}_{2}$ above 0.5 ppm caused stomatal closure while levels below $0.5 \mathrm{ppm}$ prevented complete stomatal closure.

Legge (1973) and Legge and Harvey (1974), working with seedlings of Pinus contorta, acclimated to a low growing temperature $\left(11^{\circ} \mathrm{C}\right)$, to an optimal growing temperature $\left(17.5^{\circ} \mathrm{C}\right)$, and to a high growing temperature $\left(27.5^{\circ} \mathrm{C}\right)$ prior to $\mathrm{SO}_{2}$ exposure $(0.5 \mathrm{ppm}$ for 12 hours), predisposed the test plants to an increase in transpirational water loss with increasing temperature. Relative humidity was maintained at 35-40 per cent in all these experiments. Acute symptoms appeared only on the optimally grown seedlings subjected to $\mathrm{SO}_{2}$, with all seedlings surviving. Seedlings of Pinus contorta subjected to dark stress (increase in length of dark period) and optimal growing temperature $\left(17.5^{\circ} \mathrm{C}\right)$ prior to exposure to $\mathrm{SO}_{2}(0.5 \mathrm{ppm}, 24$ hours) also displayed an increase in transpirational water loss and acute visible $\mathrm{SO}_{2}$ damage, but resulted in death.

Although there is variability in photosynthetic performance within a plant species, this laboratory work is essential for verification and comparison with photosynthetic performance of plant species in the field.

\section{$\partial_{2}$ GAS-EXCHANGE SYSTEM}

The basic open $\mathrm{CO}_{2}$ gas-exchange system developed by Salo (1974) for studies of photosynthetic performance of Douglas-fir in the field was utilized at the Windfall site. This system was modified, however, to allow for the analysis of sulfur gas emissions (specifically $\mathrm{SO}_{2}$ and $\mathrm{H}_{2} \mathrm{~S}$ ) as well as $\mathrm{CO}_{2}$. Ambient air was drawn from a height of 20 meters at the top of the canopy and was conducted to a mixing vessel through 
WEP (Eluorinated-ethylenepropylene) teflon which has been shown to have a very low adsorptivity coefficient for $\mathrm{SO}_{2}$ (regge and Harvey, 1974). After leaving the mixing vessel which had a variable volume of from 3 to 9 liters, the aix was continuously pumped to each of 3 net assimilation chambers or cuvettes (plate 4). Two of the cuvettes

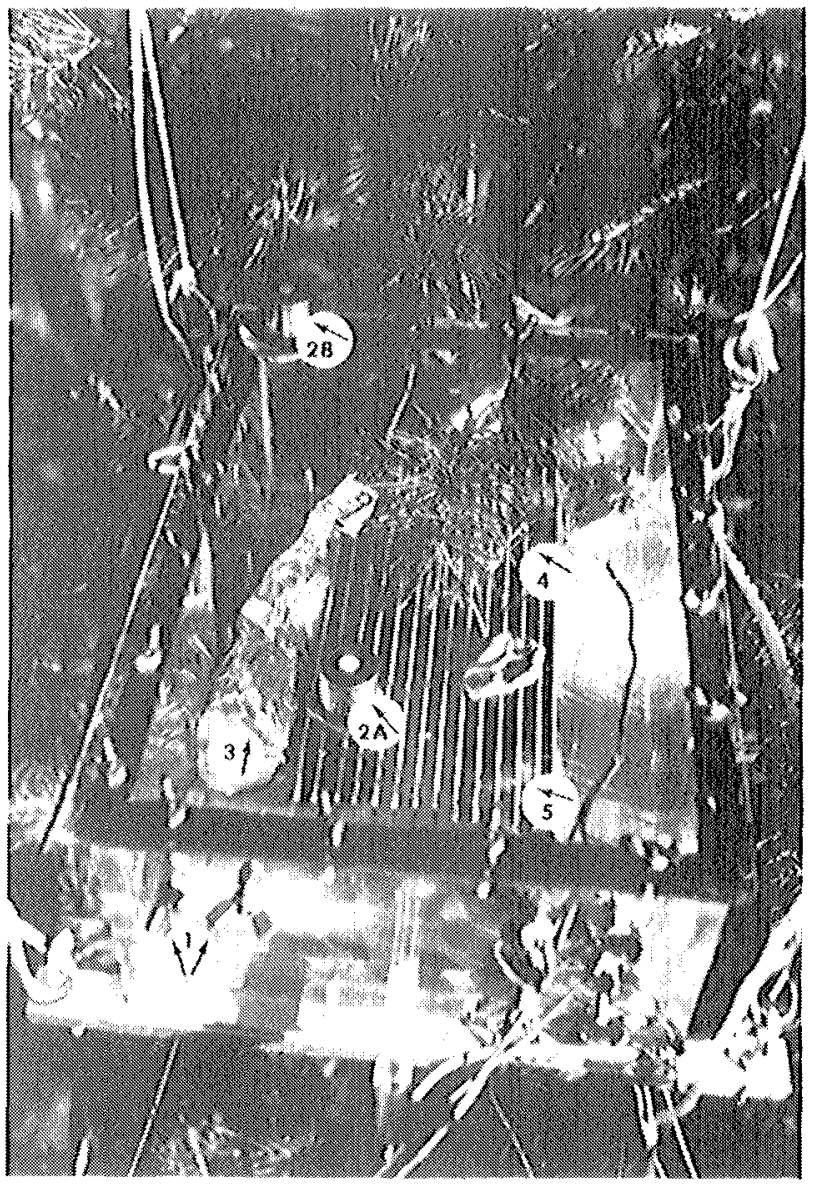

plate 4. Assimilation chamber (cuvette) for gasmexchange measurements surrounding a branch of pinus contorta/ $p$. banksiana (lodgepole pine/jack pine) hybrid at a height of: 15 meters using the access tower scaffolding.

(1) Cuvette for enclosing pine branch and measuring gasw exchange capability.

(2) Quantum sensors for measuring light:

A - internal

$B$ - external

(3) Shielded ambient air thermocouple.

(4) clipmon thermocouple for measuring needle temperature on enclosed branch.

(5) peltiex block for maintaining and controlling temperature within cuvette to the temperature outside the cuvette.

contained tree branches (1ive plant material) and the third cuvette served as a control. The assimilation chambers used were manufactured following the design of salo et a. (1972). An electric switching system was developed which permitted automatic sampling of each cuvette, thus allowing the outflow from a single cuvette to be sampled at any predetermined sampling fxequency. The switching system could also be operated manually.

The air stream being monitored was passed through a temperature stabilized vessel which contained a Hygrodynamics licl water vapox sensor and from there passed to a wet bulb/dxy bulb psychrometex (described in Bierhuizen and slatyer, 1964). The water vapor was then 
removed by a Siemens water vapor trap and passed through a Beckman IB $15 \mathrm{~A}$ absolute infrared gas analyzer. Flow rate was measured at the outlet by a Brooks precision flow meter.

By using the blank cuvette as an ambient control, the differences in $\mathrm{CO}_{2}$ and water vapor concentrations were monitored in the two sample cuvettes and net $\mathrm{CO}_{2}$ assimilation (= net photosynthesis), transpiration and leaf resistances could be calculated.

In each assimilation chamber internal ambient air temperatures and external ambient air temperatures were monitored, with Peltier cooling plates being used to maintain cuvette temperatures equal to those outside the chambers. Photosynthetically active radiation (PAR) was monitored with Lambda quantum sensors, while thermocouples were used for temperature measurements. A clip-on thermocouple (Fry, 1965) was used for the conifer needles, while fine wire thermocouple junctions were pressed against the underside of the aspen leaves.

\section{BIOMETEOROLOGY AND PLANT}

WATER STATUS

Wind speed and direction were monitored at the top of the tree canopy from the access tower scaffolding. Three sampling points were available for monitoring air quality in terms of total $\mathrm{S}, \mathrm{H}_{2} \mathrm{~S}$ and $\mathrm{SO}_{2}$. These were located above the canopy (at 20 meters), at mid-canopy (10 meters) and one meter above the ground.

Air was drawn from each sample point via FEP teflon tubing through a manually controlled glass manifold and two atmospheric sulfur gas analyzers. The 20-meter sampling point also served as the primary air intake for the $\mathrm{CO}_{2}$ open gas-exchange system. A branch line of $\mathrm{FEP}$ tubing, preceding the mixing vessels, lead to the glass manifold for the 20-meter ambient sample point.

The three cuvettes in the $\mathrm{CO}_{2}$ gas-exchange system were also connected to the sulfur analyzers via the glass manifold. Since this manifold system was manually operated, however, only air from a single sampling point (cuvette or ambient air) could be analyzed at any one time.

The two sulfur gas analyzers used were coupled together to optimize the advantages and reduce the disadvantages of each instrument. The first instrument was a Tracor model 270HA Atmospheric Sulfur Analyzer using the gas chromatographic method of analysis and a flame photometric detector (FPD). This unit automatically takes a 10cc air sample every 3 minutes and 45 seconds, and, between sampling periods, the internal instrument pumping system is bypassing air in preparation for a new sample injection. (For background information on 
the flexibility of this system for analyzing sulfur compounds other than $\mathrm{SO}_{2}$ see Brody and Chaney, 1966).

The second instrument was an Envirometrics $\mathrm{SO}_{2}$ analyzer using the polarographic method of analysis. The principle advantage of the polarographic analyzer was the capability of continuous measurement of $\mathrm{SO}_{2}$ concentration at a flow rate of 0.5 liters/minute and a response time of 30-60 seconds, depending on the age of the analytical cell or "Faristor." The main disadvantage of this analysis is the interference of $\mathrm{H}_{2} \mathrm{~S}$ to a level of 15 per cent with $\mathrm{SO}_{2}$, thus giving an apparently higher level of $\mathrm{SO}_{2}$ than is actually present in the atmosphere at the time of sampling.

The gas chromatograph permitted sensitive chromatographic separation of $\mathrm{SO}_{2}$ and $\mathrm{H}_{2} \mathrm{~S}$ in concentration ranges of $0-100 \mathrm{ppb}$ and 0-1 ppm as well as a measure of total sulfur, total $\mathrm{SO}_{2}$, and total $\mathrm{H}_{2} \mathrm{~S}$ in both high and low ranges in the sample. On the other hand, the continuous $\mathrm{SO}_{2}$ monitor enabled detection of sharp changes in $\mathrm{SO}_{2}$ concentration in the selected ranges $0-1 \mathrm{ppm}, 0-5 \mathrm{ppm}$ or $0-10 \mathrm{ppm}$ possibly missed by the gas chromatograph due to the 3 minute 45 second delay between samples.

The water status of a plant is indicated by its water potential, which can be estimated from Scholander chamber pressures measured on excised shoot samples (with the + value changed to - by convention) (Waring and Cleary, 1967). These values are reported in bars and reflect the chemical potential of free water in a plant system. Pure water is assigned a chemical potential of " 0 " and as solutes are added or the turgor pressure (water pressure on cell walls) of the plant cells decreases, this potential declines. Therefore more negative values of the water potential are indicative of decreasing chemical potential which reflects the increasing water deficit. Thus plant water deficits increase when water is lost from the plant faster than it can be resupplied by the roots. It follows that if the scholander pressure is 17 bars, the water potential is taken to be -17 bars. If there is sufficient decrease in water potential of the leaves, stomata will start to close, resulting in a reduction of transpiration. When the stomata are completely closed, transpirational water loss is negligible.

Leaf surface areas were measured using the glass bead technique of Thompson and Leyton (1971). All photosynthetic rates presented in this report were calculated on the basis of total leaf surface area.

Plant samples from all three species on which photosynthesis was determined (lodgepole pine/jack pine, white spruce and aspen) and from plants with severe damage located at or near the windfall site were returned to the University of Washington laboratory for analysis of sulfate-sulfur content. 
Scaffolding and power had been installed at the windfall study site by the time most of the equipment arrived on 9 August 1974, and the first data were collected within 12 days. The mobility of the cuvettes and the connecting lines helped to speed the initial set-up and subsequent transfer to new foliage.

\section{PINE STUDIES, CASE I}

On 1 September a small 3 meter pine located $25 \mathrm{~m}$ west of the instrument trailer was sampled (figure 4). Net assimilation (NA), or

I SEPTEMBER 1974 SMALL PINE
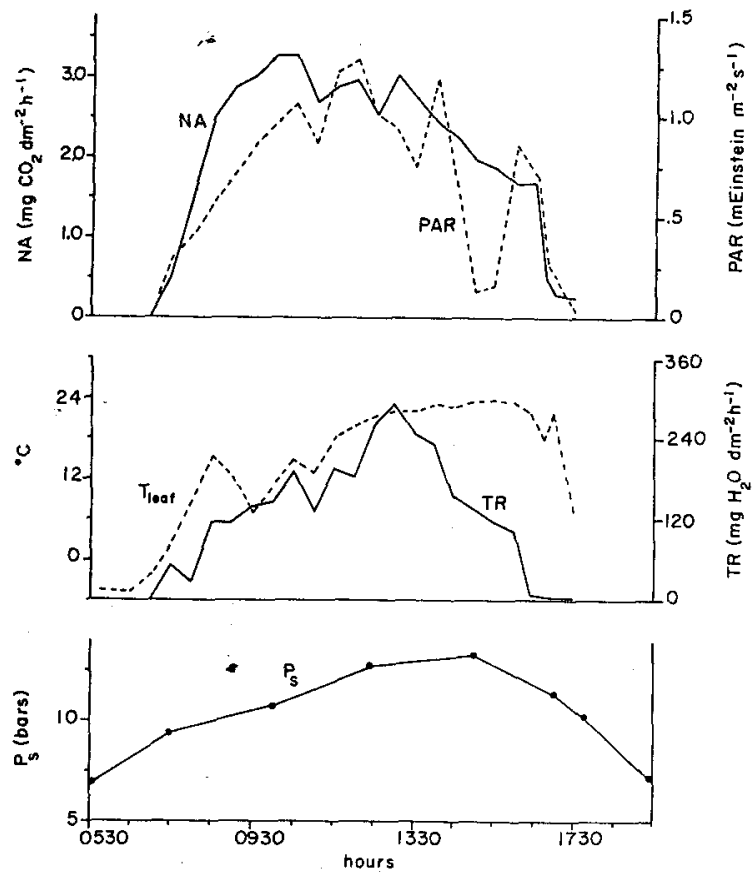

Figure 4. Net $\mathrm{CO}_{2}$ assimilation (NA) of a young 3 meter Pinus contorta/Pinus banksiana (lodgepole pine/jack pine) hybrid located $25 \mathrm{~m}$ from the instrument trailer through the course of a low temperature high solar radiation day (1 September 1974)

in relation to:

(1) PAR (Photosynthetically active radiation--400-700 nm)

(2) TR (Transpiration)

(3) $\mathrm{T}_{\text {leaf }}$ (Leaf temperature)

(4) $P_{S}$ (Scholander pressure chamber values on twigs) Note that this low temperature high radiation day prolonged the time period during which the plant would be more susceptible to air-borne pollutants since there was inadequate energy for excessive transpiration (TR).

uptake of $\mathrm{CO}_{2}$ by the plant, peaked early in the morning at approximately 1030 hours although the photosynthetically active radiation (PAR) was not at the maximum recorded for the day. Air temperatures had aropped to $-5^{\circ} \mathrm{C}$ just prior to sunrise and leaf temperatures remained low to moderate until late morning. Transpiration (TR) increased all morning with increasing leaf temperature. The transpiration peak occurred at 1300 hours or 2.5 hours after maximum net assimilation (NA) even though the photosynthetically active radiation 
was greatest at 1200 hours. This suggests partial stomatal closure but not enough to inhibit greater transpiration (TR) associated with the higher afternoon temperatures. Plant water potential $\left(\mathrm{P}_{\mathbf{S}}\right)$ dropped to less than -13 bars at 1500 hours due to substantial transpiration (TR) still taking place at that time. By 1700 hours, however, the water potential had risen by over 1.5 bars with both net assimilation (NA) and transpiration (TR) proceeding at negligible rates, indicating stomatal closure. It is not known if the low early morning temperature had any effect on net assimilation through increased mesophyll resistance (decrease in internal plant air space). The low early morning temperatures allowed for good net assimilation (NA) rates while not supplying adequate energy to drive a great amount of transpiration (TR), therefore the stomata were open longer. This low temperature high radiation day, as a result, allowed for greater photosynthate production on an area basis, but as a consequence, prolonged the time period during which the plant would be more susceptible to air-borne pollutants. The $\mathrm{SO}_{2}$ analyzers were not yet available at the site.

PINE STUDIES, CASE II

Two dominant pines approximately 20 meters tall were monitored throughout the course of the study. Scaffolding was used as access to foliage on both trees. This allowed sampling of foliage with either a south-facing or north-facing exposure and facilitated collecting the many samples needed for monitoring plant water potentials (see plate 5).

The study site experienced an $\mathrm{SO}_{2}$ episode during daylight hours on 13 September, by which time the Tracor $270 \mathrm{HA}$ and Envirometrics analyzers had been delivered to the site, tested and were operational. The early morning temperature on that day was near $0^{\circ} \mathrm{C}$, but leaf temperatures

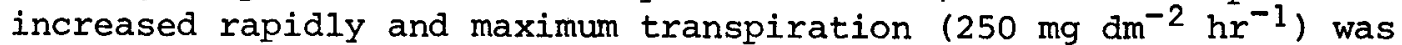
reached between 0830 and 0930 hours. Though low levels of $\mathrm{H}_{2} \mathrm{~S}$ and $\mathrm{SO}_{2}$ (20 ppb and $0.1 \mathrm{ppm}$ respectively) were measured with the Tracor unit during the previous night, only $\mathrm{SO}_{2}$ was present during this exposure which occurred at approximately 0845 (figure 5).

The cuvette was located on foliage in the north tree so that at 0930 hours the south tree began shading the foliage causing a decrease in irradiance, net $\mathrm{CO}_{2}$ assimilation and transpiration (TR). The levels of $\mathrm{SO}_{2}$ never exceeded $0.1 \mathrm{ppm}$ and it is doubtful that this low concentration for such a short period of time had any effect. If there was an effect from the $\mathrm{SO}_{2}$, it was masked by the marked decrease in light. Early morning transpiration was high enough for plant water potential to drop to -14 bars and remain at that level until 1600 hours when it began to increase. The decrease in both transpiration and net $\mathrm{CO}_{2}$ assimilation after 1100 hours indicated partial stomatal closure. Photosynthesis did not decrease as much as transpiration because of increased irradiance in the afternoon. Had there been more light in the morning the decline in photosynthesis no doubt would have been 


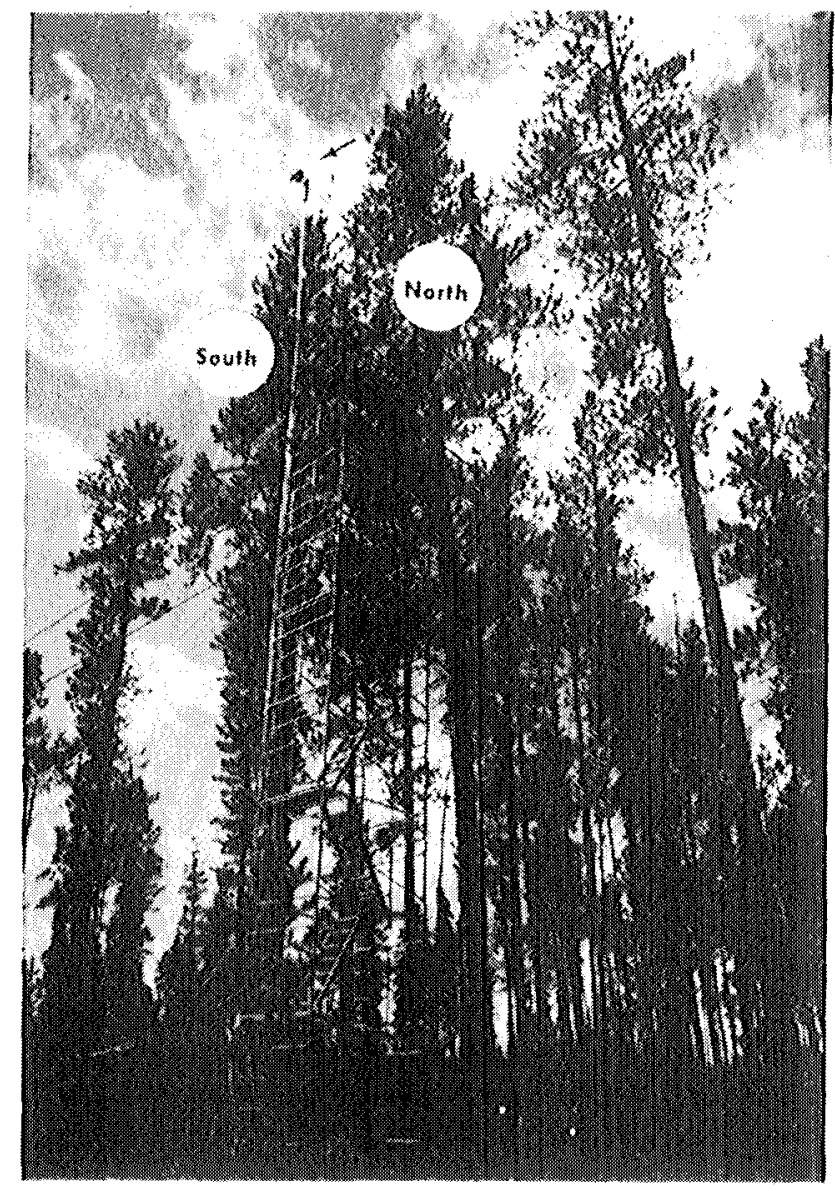

Plate 5. Wifteen meter access tower scaffolding to lodgepole pine/jack pine hybrids at the AMOCo windrall Gas plant experm imental test site. The northsouth orientation of the test trees is noted. The windfall. Gas plant is to the right (west) in the photograph. The air intake for the three cuvettes is located just under the wind speed and direction instrumen-tation (noted by the arrow) at 20 meters.

greatex. [Note: water potentials in the pines never dropped below -15 baxs during the course of the fleld woxk.]

\section{SPRUCE STUDTES}

A 3 meter spruce located $30 \mathrm{~m}$ from the instrument trailer was studied on 2 september (figure 6). The decline in net $\mathrm{CO}_{2}$ assimilation (NA) between 0930 hours and 1000 hours was caused by a decxease in irradiance (PAR) due to shading from adjacent pines. However, even with increased irradiance after 1100 hours, net assimilation did not: regain its previous rate of: $2.3 \mathrm{mg} \mathrm{dm}^{-2} \mathrm{hr} \mathrm{x}^{-1}$. Transpixation, calculated but not plotted in figure 6 , reached a maximum xate $(205 \mathrm{mg}$ $\mathrm{dm}^{-2} \mathrm{~h} \mathrm{x}^{-1}$ ) at 1000 hours and had declined to less than half that value by 1100 . This dxop in txanspixation even when there was a $3^{\circ} \mathrm{C}$ rise in leaf temperature and a 5 mb increase in vapor pressure deficit, indicated that stomata were closing. plant water potential decreased to -17 baxs (1 bar $=0.987$ atm) by 1330 hours from a predawn value of -10 baxs and remained at that level for at least an hour during which 


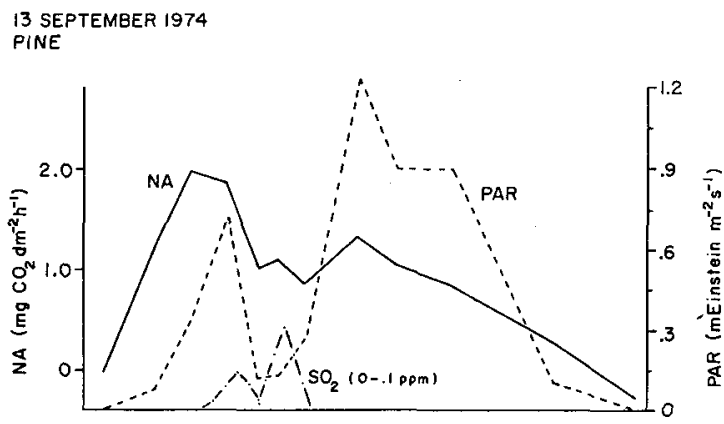

Figure 5. Net $\mathrm{CO}_{2}$ assimilation (NA) at the 15 meter level in a $P$ inus contorta/Pinus banksiana (lodgepole pine/jack pine) hybrid through the course of a high temperature moderate solar radiation (scattered clouds) day (13 September 1974) in relation to:

(1) PAR (Photosynthetically active radiation- $-400-700 \mathrm{~nm}$ )

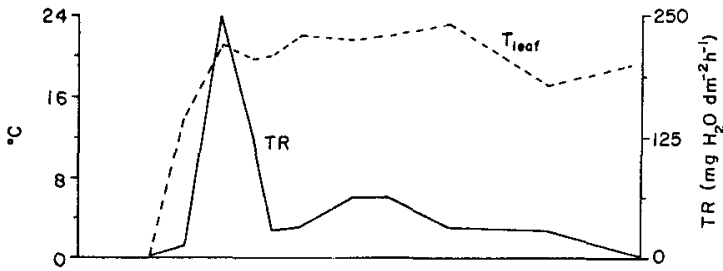

(2) $\mathrm{SO}_{2}$ (in the cuvette air)

(3) TR (Transpiration)

(4) $T_{\text {leaf }}$ (Leaf temperature)

(5) vpd (Water vapor pressure deficit in the air)

(6) $\mathrm{P}_{\mathrm{S}}$ (Scholander pressure chamber values on twigs)

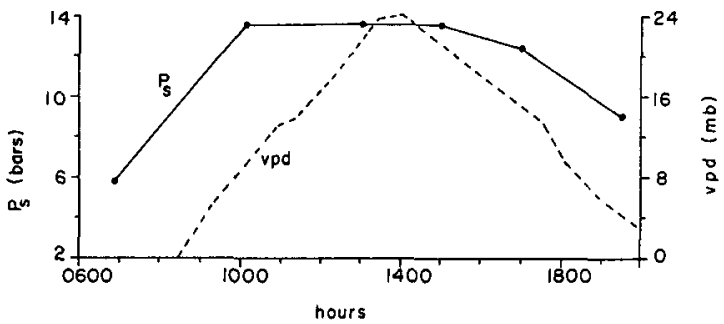

Stomatal closure is indicated by the rapid decrease in transpiration. (TR) rate beginning at 0900 hours. The stomata were mostly closed during the remainder of the day. Despite the fact that clouds covered the sun during the $\mathrm{SO}_{2}$ episode as indicated by the rapid decrease of photosynthetically active radiation (PAR), it is doubtful that this low concentration of $\mathrm{SO}_{2}$ for such a short period of time had any effect. The stomata were also closing at this same time.

time transpiration had virtually ceased. By mid-afternoon, however, water uptake by the tree had resupplied enough water to decrease the plant water deficit by 2 bars.

\section{ASPEN STUDIES}

A 2 meter aspen located $30 \mathrm{~m}$ from the instrument trailer was studied on 22 August (figure 7). Net assimilation (NA) and leaf temperature ( $T_{\text {leaf }}$ ) clearly followed irradiance through the course of the day, indicating that photosynthesis was light limited most of the day. The maximum value of net assimilation was $3 \mathrm{mg} \mathrm{dm}^{-2} \mathrm{hr}^{-1}$. Scholander readings were not taken on the aspen at this time, but early morning readings on the pines showed water potentials above -5 bars 
2 SEPT'EMBER 1974

SPRUCE
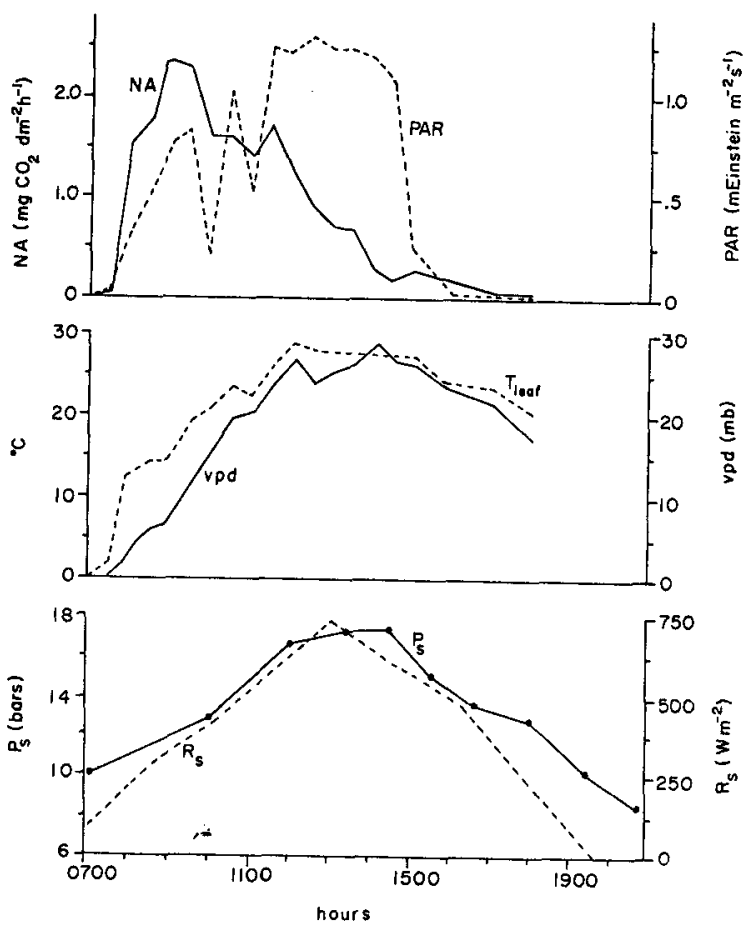

22 AUGUST 1974

ASPEN
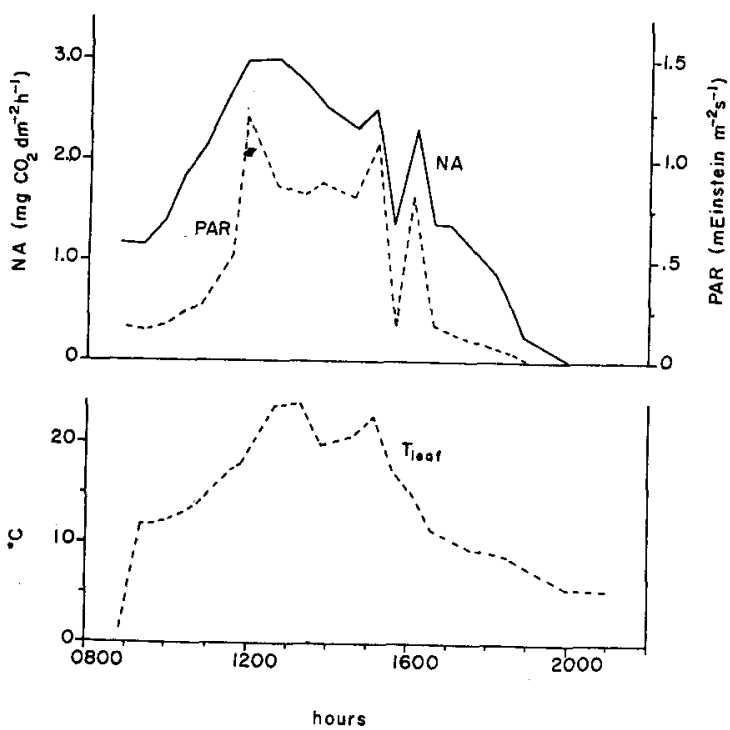

Figure 6. Net $\mathrm{CO}_{2}$ assimilation (NA) of a Picea glauca (White spruce) sapling through the course of a moderate to low solar radiation and high temperature day (2 September 1974) in relation to:

(1) PAR (Photosynthetically active radiation- $-400-700 \mathrm{~nm}$ )

(2) $R_{S}$ (Total solar energy at top of stand)

(3) $\mathrm{T}_{\text {leaf }}$ (Leaf temperature)

(4) vpd (Water vapor pressure deficit in the air)

(5) $\mathrm{P}_{S}$ (Scholander pressure chamber values on twigs) Note the initial rapid increase in net assimilation (NA) and the gradual drop in NA throughout the remainder of the day despite adequate photosynthetically active radiation (PAR). This tree is in a condition of marginal water stress at this time.

Figure 7. Net $\mathrm{CO}_{2}$ assimilation (NA) of an aspen (Populus tremuloides) through the course of a high solar radiation low temperature day (22 August 1974) in relation to:

(1) PAR (Photosynthetically active radiation-- $400-700 \mathrm{~nm}$ )

(2) $\mathrm{T}_{\text {leaf }}$ (Leaf temperature)

Note that net assimilation (NA) and leaf temperature (Tleaf) follow photosynthetically active radiation (PAR). 
which indicated adequate soil moisture. Ample soil moisture and relatively low air temperatures would aid in maintaining a wide stomatal aperture for most of the day.

\section{FOLIAR SULFATE ANALYSIS}

Foliage samples were taken from each of the plants monitored with the $\mathrm{CO}_{2}$ gas-exchange system and from others which showed severe damage. These samples were dried and tested for sulfate-sulfur using the methylene blue colorimetric method of Johnson and Nishita (1952). Results have indicated high sulfate-sulfur levels (between 300 and 700 ppm), but too few samples were collected and analyzed to establish the relationship between sulfate accumulation and time. In one instance in which two age classes from the same branch were tested, the older foliage had a somewhat higher sulfate-sulfur concentration than the younger foliage. More research is required in this area to determine the role of sulfate build-up in plant tissues and sulfate toxicity.

PLANT CANOPY AND SULFUR

GAS EMISSIONS

An $\mathrm{SO}_{2}$ concentration gradient was detected using the three-point ambient air sampling system affixed to the 15 meter access scaffolding in the lodgepole pine/jack pine study site. During a fumigation concentrations of $\mathrm{SO}_{2}$ were generally greater in the upper portion of the canopy $(0.1 \mathrm{ppm}$ above and 0.05 below). Under these conditions the stand crown was providing an adequate barrier to dispersal of emissions throughout the stand. This situation was reversed on several occasions with the lower sample point being $0.1 \mathrm{ppm}$ and the value above the canopy being $0.05 \mathrm{ppm}$ or below. The relationship can best be explained by advection of sulfur gas emissions from the gas plant into the leading edge of the stand. With little or no convection and the semi-closed nature of the plant canopy the $\mathrm{SO}_{2}$ was removed by further advection and subsequent dilution.

\section{DISCUSSION}

For any plant to grow and maintain itself it must have a good rate of net $\mathrm{CO}_{2}$ assimilation. This $\mathrm{CO}_{2}$ uptake can be limited by different environmental factors acting on the photosynthetic apparatus and stomata. It is known that soil moisture, relative humidity, temperature and irradiance all affect photosynthesis through changes in stomatal aperture and it is therefore imperative that these environmental variables be monitored at all times when assessing net $\mathrm{CO}_{2}$ assimilation. 
Little information $i s$ available on how $\mathrm{SO}_{2}$ affects photosynthesis, although it has been suggested that dixect effects occur through enzyme-SO $\mathrm{S}_{2}$ interactions (Tanaka et a.., 1974; Zeigler, 1974). A majority of woxkexs supports the position that low levels of $\mathrm{SO}_{2}$ for short periods of time are relatively harmless, and at times can supply needed sulfur, but when long time intervals are involved with multiple exposures, the probability of visual damage or decline in $\mathrm{CO}_{2}$ assimilation (limited photosynthetic capacity and hence decreased productivity) is enhanced.

The vegetation at the windfall site is quite chlorotic and much of the foliage is being cast earliex than normal. for both the pine and spruce (see plate 6). Several of the trees nearest the gas plant show

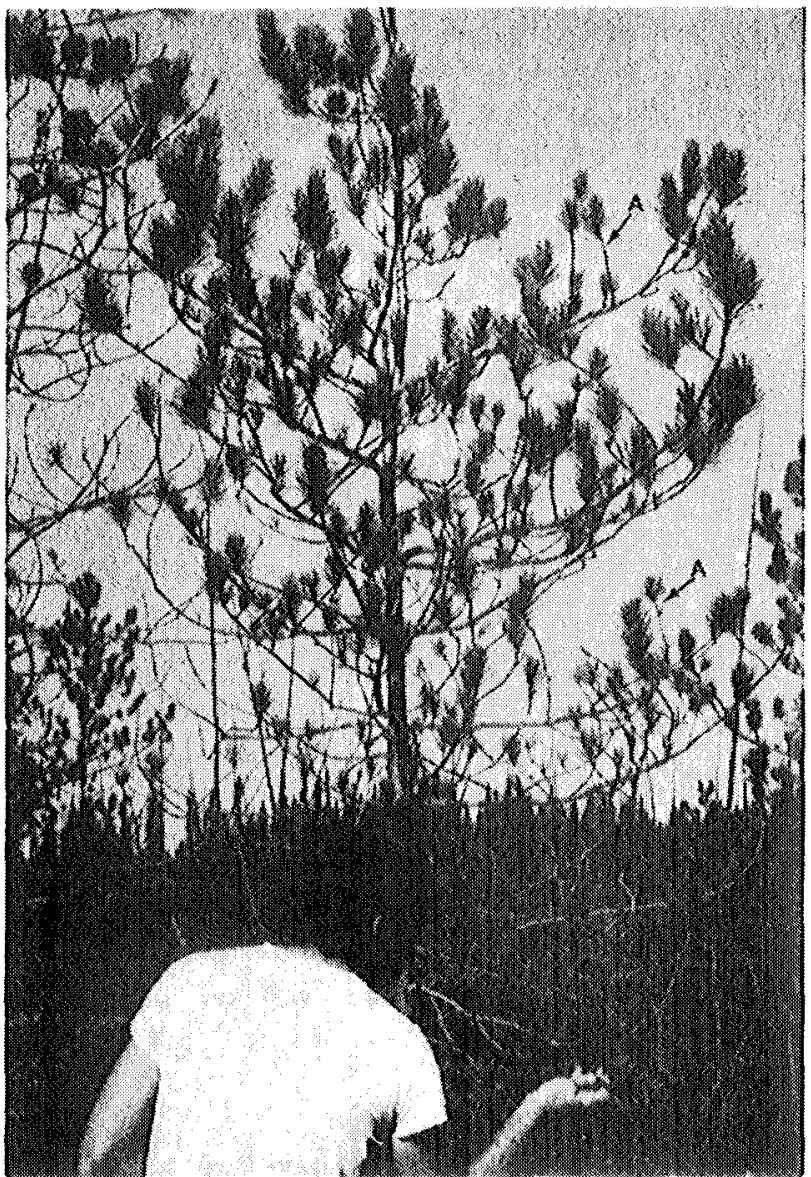

plate 6. pinus contorta/p. banksiana (lodgepole pine/jack pinel hybrid on windward (west) side of expeximental site relative to the windfall Gas plant showing $\mathrm{SO}_{2}$ symptoms such as premature needle drop (A) and growth retardation.

signs of acute $\mathrm{SO}_{2}$ damage with severe growth retardation. There apparently is eithex a filtering action by the leading edge of the stand (biological sink) or, more likely, the stand limits air flow from the direction of the gas plant and thus reduces the number and/ox severity of exposures. 
Dykstra (1974) reported maximum net photosynthetic rates of $10 \mathrm{mg}$ $\mathrm{dm}^{-2} \mathrm{hr}^{-1}$ (projected needle area basis) in Pinus contorta seedlings. Direct comparison of his values with those reported here based on total surface area are misleading. A conservative conversion of Dykstra's values to total area would place the maximum rates between $4-5 \mathrm{mg} \mathrm{dm}^{-2}$ $\mathrm{hr}^{-1}$. The maximum photosynthetic rate monitored in the pines at the Windfall site was $3.28 \mathrm{mg} \mathrm{dm}^{-2} \mathrm{hr}^{-1}$. Van Zindern Bakker (1974) observed a maximum rate in the field of $6 \mathrm{mg} \mathrm{gDW}^{-1} \mathrm{hr}^{-1}$ for black spruce. Since the ratio of grams to $\mathrm{dm}^{2}$ in conifer foliage is normally less than one, converting a rate from a dry weight to an area basis would decrease the magnitude of the rate. The highest rate calculated for the spruce at the Windfall site was $2.3 \mathrm{mg} \mathrm{dm^{-2 }} \mathrm{hr}^{-1}$. All of the samples showed less than expected photosynthetic rates, but due to the approach of autumn it is possible that senescence was a factor in the low rates for aspen ( $3 \mathrm{mg} \mathrm{dm}^{-2} \mathrm{hr}^{-1}$ ). It is doubtful that the conifers were influenced by the onset of dormancy, but Van zinderen Bakker (1974) observed that photosynthesis can be reduced when low temperatures (less than $-2 \mathrm{C}$ ) occur, even during the summer. Neilson et al. (1972) working on Sitka spruce (Picea sitchensis (Beng.) Carr.) attributed such drops in photosynthesis to increases in mesophyll resistance.

Throughout the course of the field study plant water potentials in pine did not fall below -15 bars, while plant water potentials of -18 bars were recorded for spruce. At those minimum plant water potentials, transpiration in both species was greatly reduced. These results agree with those of Lopushinsky and Klock (1974) who found that the stomata of pines are more sensitive to decreasing leaf water potentials than the spruce. On days of high evaporative demand, the stomata of pine tend to close earlier than those of spruce and are less susceptible to air-borne pollutants under these conditions.

CONCLUSION

This preliminary investigation was seen as an extension of the controlled laboratory $\mathrm{SO}_{2}$ fumigation experiments conducted by the Environmental Sciences Centre (Kananaskis), University of Calgary, for the Whitecourt Environmental Study Group.

Initial results from the field research indicate the following:

(1) The vegetation around the Windfall Gas Plant is basically characterized by two habitat types which repeat themselves across the landscape. These are the moist bogs and well-drained sand dune sites which are classified phytosociologically as a Pinus-Picea glauca/ Arctostaphylos uva-ursi. (pine-white spruce/bearberry) association and a Picea mariana/Ledum-Sphagnum (black spruce/Labrador tea-sphagnum) bog association. 
(2) $\mathrm{SO}_{2}$ and $\mathrm{H}_{2} \mathrm{~S}$ in the atmosphere were found to be extremely variable with levels generally below ambient air quality standards.

(3) A concentration gradient of $\mathrm{SO}_{2}$ was found to exist in the lodgepole pine/jack pine stand where the gas-exchange experiments were undertaken, with the $\mathrm{SO}_{2}$ values above the plant canopy generally higher than levels below the plant canopy $10.1 \mathrm{ppm}$ above and 0.05 below). This relationship was occasionally reversed.

(4) Lower than expected photosynthetic rates were observed for lodgepole pine, spruce and aspen.

(5) Unusually high sulfate-sulfur levels were found in plant material of lodgepole pine.

(6) Visible chronic $\mathrm{SO}_{2}$ symptoms on plant material were more common on the windward side of the experimental site relative to the Windfall Gas Plant.

(7) Visible chronic $\mathrm{SO}_{2}$ symptoms had a pronounced sun, or upward, orientation. This fact was experimentally verified in the laboratory.

The vegetative environment around the Windfall Gas Plant is definitely affected by sulfur gas emissions, but the extent remains to be determined.

\section{RECOMMENDATIONS}

It is critical that further research place particular emphasis on the transfer processes that affect the movement of sulfur gas emissions from their source to their contact with the vegetation through the stomata down to the molecular level. When it is known how these processes are modified and under what conditions, we can begin to estimate the effect.

Specific recommendations for further studies into the effects of sulfur gas emissions on vegetation are:

(1) Air quality monitoring trailers need to monitor environmental parameters which modify plant response such as soil moisture, relative humidity and photosynthetically active radiation (PAR) in addition to wind speed/direction, concentration of pollutants and temperature.

(2) Paired plot studies based on ecologically similar sites, determined by phytosociological analysis, between affected and unaffected locations of basal area growth rates in black spruce, white spruce, birch and/or aspen should be undertaken. A similar study 
should also be done with mosses, liverworts and lichens epiphytic on given tree species.

(3) Analysis of plant macronutrients, particularly nitrogen and phosphorous, should be conducted. At present nitrogen dificiency cannot be eliminated as a possible contributing factor to the general chlorotic dondition of the vegetation around the windfall plant.

(4) Controlled $\mathrm{SO}_{2}$ fumigations of plant species under field conditions to determine on-site responses should be undertaken.

(5) Key plant metabolites such as chlorophyll (total chlorophyll, chlorophyll a, and chlorophyll b) pigments, carotenoid pigments, Adenosine triphosphate (ATP), soluble sugars, amino acids, total sulfur and sulfate-sulfur should be monitored to determine the metabolic status of vegetation exposed to sulfur-gas emissions

(6) Plant water and soil water relations should be monitored seasonally to determine plant and soil water flux.

(7) Micrometeorology and its relation to sulfur-gas emissions should be studied to obtain a measure of the $\mathrm{SO}_{2} / \mathrm{H}_{2} \mathrm{~S}$ concentration to which a defined plant canopy is exposed and the major environmental parameter fluctuations during this exposure.

\section{ACKNOWLEDGEMENTS}

This work would not have been possible without grants from the following agencies to the Environmental Sciences Centre (Kananaskis), University of Calgary:

(1) Whitecourt Environmental study Group,

(2) Research Secretariat, Alberta Environment,

(3) Oil Sands Environmental Study Group, and

(4) UNISUL (University of Calgary Interdisciplinary

Sulfur Research Group).

In addition to data collected at the study site, air quality data were made available by AMOCO from their Windfall Gas Plant and at the Whitecourt headquarters. Thanks are extended to Mr. Byron G. Scott for valuable technical assistance, and to $\mathrm{Dr}$. David J. Salo for indispensable advice on equipment and methodology. 
Bierhuizen, J. F. and R. O. Slatyer. 1964. Photosynthesis and transpiration under controlled environmental conditions. In: TECH. BULL. \#36. Institute for Land and Water Management Research, Wageningen, The Netherlands.

Bowen, H. J. M. 1965. Sulphur and the Distribution of British Plants. WATSONIA. $6(2): 114-119$.

Brody, S. S. and J. E. Chaney. 1966. The Application of a Specific Detector for Phosphorous and for sulfur Compounds--Sensitive to Subnanogram Quantities. JOURNAL OF GAS CHROMATOGRAPHY. February 1966, 42-46.

Daines, R. H. 1968. $\mathrm{SO}_{2}$ and Plant Response. JOURNAL OF OCCUPATIONAL MEDICINE. $10(9): 516-534$.

Daubenmire, R. F. and J. B. Daubenmire. 1968. FOREST VEGETATION OF EASTERN WASHINGTON AND NORTHERN IDAHO. Washington Agricultural Experiment Station Tech. Bull. \#60.

Dykstra, G. F. 1974. Photosynthesis and carbon dioxide transfer resistance of lodgepole seedlings in relation to irradiance, temperature, and water potential. CANADIAN JOURNAL OF FOREST RESOURCES. 4:201-206.

FrY, K. E. 1965. A STUDY OF TRANSPIRATION AND PHOTOSYNTHESIS IN RELATION TO THE STOMATAL RESISTANCE AND INTERNAL WATER POTENTIAL IN DOUGLAS-FIR. Ph.D. dissertation. Univ. of Washington, Seattle.

Guderian, R. and $\mathrm{H}$. Van Haut. 1970. Detection of $\mathrm{SO}_{2}$-effects upon plants. STAUB-REINHALT. Luft $30(1): 22-35$.

Halliday, W. E. D. 1937. A FOREST CLASSIFICATION FOR CANADA. Canadian Forestry Service Bull. \#89. 50 pp.

Hickling, L. L. 1974. THE EFFECTS OF $\mathrm{SO}_{2}$ FUMIGATION ON NET PHOTOSYNTHESIS OF DOUGLAS-FIR. M. SC. Thesis. Univ. of Washington, Seattle.

Johnson, C. M. and H. Nishita. 1952. Microestimations of sulfur in plant materials, soils and irrigation water. ANALYTICAL CHEMISTRY $24: 736-742$.

Legge, A. H. 1973. Sulphur Dioxide and Environmental Prestressing of Vegetation. In: WHITECOURT ENVIRONMENTAL STUDY - 1973. 
Legge, A. H. and G. W. Harvey. 1974. Sulfur Dioxide and Environmental. Preconditioning of Vegetation. In: WHITECOURT ENVIRONMENTAL STUDY - 1974.

Lopushinsky, W. and G. O. Klock. 1974. Transpiration of conifer seedlings in relation to soil water potential. FOREST SCIENCE. $20(2): 181-186$.

Majernik, O. and T. A. Mansfield. 1970. Direct effect of $\mathrm{SO}_{2}$ pollution on the degree of opening of stomata. NATURE. 277: $377-378$.

Majernik, O. and T. A. Mansfield. 1971. Effects of $\mathrm{SO}_{2}$ pollution on stomatal movements in Vicia faba. Phytopath. Z. 71:123-128.

Mansfield, T. A. and O. Majernik. 1970. Can stomata play a part in protecting against air pollution. ENVIRONMENTAL POLLUTION. $1: 149-154$.

Meidner, H. and T. A. Mansfield. 1968. PHYSIOLOGY OF STOMATA. McGraw Hill, New York and London.

Neilson, R. E., M. M. Ludlow and P. G. Jarvis. 1972. Photosynthesis in Sitka Spruce (Picea sitchensis (Bong.) Carr.) II. Response to temperature. JOURNAL OF APPLIED ECOLOGY. 9:721-754.

Pike, L. H., W. C. Denison, D. M. Tracy, D. Nielsen, M. A. Sherwood, and F. M. Rhoades. 1975. A FLORISTIC SURVEY OF THE EPIPHYTIC LICHENS AND BRYOPHYTES GROWING ON THE TRUNK, BRANCHES, AND TWIGS OF LIVING OLD-GROWTH CONIFERS IN WESTERN OREGON. (unpubl. manuscript).

Rowe, J. S. 1972. FOREST REGIONS OF CANADA. Department of the Environment, Canadian Forest Service Publication \#1300. 172 pp.

Salo, D. J. 1974. FACTORS AFFECTING PHOTOSYNTHESIS IN DOUGLAS-FIR. Ph.D. dissertation. Univ. of Washington, Seattle.

Salo, D. J., J. A. Ringo, J. H. Nishitani and R. B. Walker. 1972. Development and testing of an inexpensive thermoelectrically cooled cuvette. In: PROCEEDINGS -- RESEARCH ON CONIFEROUS FOREST ECOSYSTEMS -- A SYMPOSIUM. (J. F. Franklin, L. J. Dempster and R. H. Waring, eds.). Pacific Northwest Forest and Range Station, Portland.

Scheffer, T. C. and G. C. Hedgecock. 1955. INJURY TO NORTHWEST FOREST TREES BY SULFUR DIOXIDE FROM SMELTERS. USDA Tech. Bull. \#1117. 
Skorepa, A. C. and D. H. Vitt. 1975. A QUANTITATIVE ANALYSIS OF LICHEN VEGETATION IN RELATION TO $\mathrm{SO}_{2}$ POLLUTION AT ROCKY MOUNTAIN HOUSE, ALBERTA. Alberta Sulphur Gas Research Workshop II, January 16-17, 1975. Environmental Sciences Centre (Kananaskis).

Stratmann, H. and H. Van Haut. 1960. Experimentelle Untersuchungen uber die Wirkung von Schwefeldioxyd auf die vegetation, in FORSCHUNGBERICHTE DES LANDES NORDRHEIN-WESTFALEN, $24 \mathrm{pp}$.

Tamm, C. O. and A. Aronsson. 1972. PLANT GROWTH AS AFFECTED BY SULFUR COMPOUNDS IN A POLLUTED ATMOSPHERE. \#12 in a series. Research notes from the Dept. of Forest Ecology and Forest Soils, College of Forestry. Stockholm. 54 pp.

Tanaka, H., T. Takanashi and M. Yatazawa. 1974. Experimental studies on $\mathrm{SO}_{2}$ injuries in higher plants. III. Inhibitory effect of sulfite ion on $\mathrm{CO}_{2}$ fixation. WATER, AIR AND SOIL POLLUTION. $3(1): 11-16$.

Thomas, M. D. 1961. Effects of air pollution on plants. In: AIR POLLUTION. World Health Organization Monograph Series \#46.

Thomas, M. D. and G. R. Hill. 1937. Relation of sulfur Dioxide in the Atmosphere to Photosynthesis and Respiration of Alfalfa. PLANT PHYSIOLOGY. $12: 309-383$.

Thomas, M. D., R. H. Hendricks and G. R. Hill. 1950. Sulfur content of vegetation. SOIL SCIENCE. 70:9-18.

Thompson, F. B. and L. Leyton. 1971. Method for measuring the leaf surface area of complex shoots. NATURE. 229:572-573.

Ulrich, A., M. A. Tabatabai, K. Ohki and C. M. Johnson. 1967. Sulfur content of alfalfa in relation to growth in filtered and unfiltered air. PIANT AND SOIL. $26(2): 235$.

Bakker, E. M. Van Zinderen. 1974. AN ECOPHYSIOLOGICAL STUDY OF BLACK SPRUCE IN CENTRAL ALBERTA. Ph.D. dissertation, Univ. of Alberta, Edmonton.

Waring, R. H. and B. D. Cleary. 1967. Plant moisture stress: Evaluation by pressure bomb. SCIENCE. 155:1248-1254.

Westman, I. 1974. Air Pollution Indications and Growth of Spruce and Pine near a Sulfite Plant. AMBIO. 3(5): 189-193.

Whittaker, R. H. 1956. Vegetation of the Great Smoky Mountains. ECOLOGICAL MONOGRAPHS. $26: 1-80$. 
Ziegler, I. 1974. Properties and inhibition by sulfite. BIOCHEMICA ET BIOPHYSICA ACTA. 364:28-37. 